\title{
Materi Himpunan Terintegrasi Keislaman: Sebuah Studi Pengembangan Perangkat Pembelajaran berbasis Model Problem Based Learning
}

\author{
${ }^{1}$ Nurmala Sari, ${ }^{2}$ Sri Rezeki, ${ }^{3}$ Rezi Ariawan \\ Program Studi Pendidikan Matematika, Universitas Islam Riau \\ Jl. Kaharuddin Nasution No.113 Perhentian Marpoyan, Pekanbaru, Riau, Indonesia \\ E-mail: ${ }^{1}$ sarinurmala260@yahoo.com
}

Received: dd-mm-yyyy; Received in revised form: dd-mm-yyyy; Accepted: dd-mm-yyyy;

Available online: dd-mm-yyyy

\begin{abstract}
The purpose of this study is to produce a mathematical learning tool developed based on Islamic Integrated Problem-Based Learning (PBL) model that meets the validity criteria and practicality in which this learning device will make students able to solve problems related to Islam. Learning tools developed in the form of RPP (learning implementation plan) and LKPD (student worksheets) Problem-Based Learning (PBL) Islamic Integrated Model. The development of learning tools in this study uses a modification of $R \& D$ from Sugiyono so that it becomes several stages, namely: (1) Potential and problems; (2) data collection; (3) Product design; (4) Design validity; (5) Design revisions; (6) Product testing; (7) Product revision; and (8) Final product. This product was developed in class VII of SMP. The instruments of this study were the validation sheets of RPP and LKPD with Islamic Integrated, practicality questionnaire of RPP and LKPD and questionnaire for implementation of integrated Islamic learning. Islamic integration referred to in this development research by incorporating knowledge about Islam such as: the names of figures in Islam. From the research, the validation of RPP with validity criteria is quite valid and the results of the validation of $L K P D$ with validity criteria are quite valid. While the results of the practicality of lesson plans with very practical criteria and the results of practical LKPD obtained from student questionnaire responses with very practical criteria, as well as the average results of the implementation of learning. Based on this research development produces a mathematical learning device Problem-Based Learning (PBL) model of Islam in the material of the SMP VII Class Association tested its feasibility.
\end{abstract}

Keywords: Development of Learning Devices; Problem-Based Learning (PBL); Islamic Integrated.

\begin{abstract}
Abstrak
Tujuan dari penelitian ini adalah untuk menghasilkan Perangkat pembelajaran matematika yang dikembangkan berdasarkan model Problem-Based Learning (PBL) Terintegrasi Keislaman yang memenuhi kriteria kevalidan dan kepraktisan yang mana perangkat pembelajaran ini akan menjadikan siswa mampu menyelesaikan masalah yang terkait dengan keislaman. Perangkat pembelajaran yang dikembangkan berupa RPP (Rencana pelaksanaan pembelajaran) dan LKPD (Lembar kerja peserta didik) model Problem-Based Learning (PBL) Terintegrasi Keislaman. Pengembangan perangkat pembelajaran dalam penelitian ini menggunakan modifikasi $R \& D$ dari Sugiyono sehingga menjadi beberapa tahap yaitu: (1) Potensi dan masalah; (2) pengumpulan data; (3) Desain produk; (4)
\end{abstract}


Validitas desain; (5) Revisi desain; (6) Uji coba produk; (7) Revisi produk; dan (8) Produk akhir. Produk ini dikembangkan pada kelas VII SMP. Instrumen penelitian ini adalah lembar validasi RPP dan LKPD dengan Terintegrasi Keislaman, angket kepraktisan RPP dan LKPD dan angket keterlaksanaan pembelajaran yang Terintegrasi keislaman. Terintegrasi keislaman yang dimaksud dalam penelitian pengembangan ini dengan memasukkan pengetahuan tentang islam seperti: nama-nama tokoh-tokoh dalam islam. Dari penelitian diperoleh hasil validasi RPP dengan kriteria kevalidan cukup valid dan hasil validasi LKPD dengan kriteria kevalidan cukup valid. Sedangkan hasil kepraktisan RPP dengan kriteria sangat praktis dan hasil kepraktisan LKPD diperoleh dari angket respon siswa dengan kriteria sangat praktis, serta rata-rata hasil keterlaksanaan pembelajaran. Berdasarkan penelitian pengembangan ini menghasilkan perangkat pembelajaran matematika model Problem-Based Learning (PBL) Terintegrasi keislaman pada materi Himpunan kelas VII SMP teruji kelayakannya.

Kata Kunci: Pengembangan Perangkat Pembelajaran; Problem-Based Learning (PBL); Integrasi Keislaman

\section{Pendahuluan}

Perkembangan atau perubahan pendidikan terjadi sejalan dengan kemajuan teknologi. Perubahan dengan maksud memperbaiki sistem pendidikan Indonesia menjadi lebih bermutu untuk menyiapkan generasi muda yang siap menyonsong perubahan dunia yang begitu cepat. Pendidikan adalah bentuk perwujudan yang dinamis terhadap perkembangan, sehingga perkembangan pendidikan adalah perubahan dari budaya kehidupan ${ }^{1}$. Lebih lanjut dipertegas bahwa dalam membentuk pribadi yang baik, untuk membangun kehidupan bangsa masa kini dan masa mendatang maka pendidikan berakar pada budaya bangsa ${ }^{2}$. Pendidikan yang seperti ini sangatlah perlu dalam sebuah pembelajaran pada zaman teknologi (modern) dan mengandung nilai keislaman yang sangat kuat dan diperlukan usaha yang maksimal untuk mengarahkan manusia kedalam tatanan nilai. Lebih lanjut dikatakan bahwa suatu pendidikan nilai moral bukan hanya berguna bagi suatu individu secara akademik saja namun sangat berguna bagi non akademik ${ }^{3}$.

Dalam hal ini individu yang menyangkut di dalamnya membuat kesepakatan serta membuat suatu individu nyaman dan berkembang dengan lingkungan belajarnya ${ }^{4}$. Dalam pengalaman belajar yang sangat luas

${ }^{1}$ Sofan Amri, Pengembangan Dan Model Pembelajaran Dalam Kurikulum 2013 (Jakarta: Prestasi Pustaka, 2013).

2 Kunandar, Penilaian Autentik (Penilaian Hasil Belajar Peserta Didik Berdasarkan Kurikulum 2013) (Jakarta: PT. Rajagrafindo Persada, 2014).

${ }^{3}$ Nani Fitriah, Arif Muchyidin, and Jamali Sahrodi, "Implementasi Model Pembelajaran Matematika Berintegrasi Keislaman Dalam Meningkatkan Karakter Demokrasi Siswa," Eduma : Mathematics Education Learning and Teaching 4, no. 2 (June 4, 2015), https://doi.org/10.24235/eduma.v4i2.34.

${ }^{4}$ Fitriah, Muchyidin, and Sahrodi. 
sehingga apa yang disampaikan tersebut akan pelajaran yang mengandung berbagai muatan yang bernilai positif. Dalam hal ini bahan ajar berperan dalam menunjang aktivitas peserta didik di kelas, dimana bahan ajar yang dapat digunakan oleh guru adalah buku cetak dan Lembar Kerja Peserta Siswa (LKPD). disajikan dengan melibatkan peserta didik yang secara aktif maka akan membantu guru untuk dapat lebih dekat dengan peserta didik akibat kegiatan-kegiatan yang dilakukannya. Dalam pengembangan perangkat pembelajaran ini diperlukan juga sebuah model, dimana model yang akan digunakan dalam sebuah kurikulum pembelajaran akan sangat berperan penting dalam menyampaikan sebuah materi pembelajaran.

Mampu menciptakan lingkungan belajar yang baik dan dapat membantu peserta didik mengamati masalah dan memecahkannya dalam pembelajaran berbasis masalah. Pembelajaran yang di dasarkan pada permasalahan yang banyak membutuhkan penyelidikan autentik dalam menyelesaikan masalah yang nyata ${ }^{5}$.

Langkah-langkah pembelajaran berbasis masalah adalah sebagai berikut: 6

1) Mengamati masalah

2) Menanya, memunculkan permasalahan

3) Menalar, mengumpulkan data

4) Mengasosiasi, merumuskan jawaban

5) Mengomunikasikan

Dalam pembelajaran juga perlu memadukan pembelajaran dengan meteri lain atau dengan memadukan nilai moral dan akhlah. Pembelajaran tidak hanya mengantarkan siswa pada ketercapaian pengetahuan (domain kognitif), tetapi juga ketercapaian pemahaman dan penerapan nilai-nilai islam 7. Pembelajaran terintegrasi keislaman di mana pembelajaran ini dipadukan dengan nilai islami yang berkenaan dengan ketercapaian moral dan perilaku yang bertujuan untuk mengembangkan potensi setiap siswa menjadi seutuhnya, tidak hanya cerdas secara intelektual tetapi juga cerdas secara emosional maupun spiritual.

Berdasarkan hasil observasi penulis terhadap SMP Muhammadiyah 2 Pekanbaru masih diperoleh beberapa masalah berkenaan LKPD dalam proses pembelajaran matematika: 1) LKPD tidak memiliki warna, format tulisan yang biasa saja; 2) LKPD hanya berisikan soal-soal saja; 3) LKPD yang digunakan

\footnotetext{
5 Trianto, Model Pembelajaran Terpadu Dalam Teori Dan Praktek (Jakarta: Prestasi Pustaka, 2007).

${ }^{6}$ E Kosasih, Strategi Belajar Dan Pembelajaran Implementasi Kurikulum 2013 (Bandung: Yrama Widya, 2014).

7 Nihayati Nihayati, "Integrasi Nilai-Nilai Islam Dengan Materi Himpunan (Kajian Terhadap Ayat-Ayat Al-Qur'an)," Jurnal E-DuMath 3, no. 1 (January 30, 2017), https://doi.org/10.26638/je.285.2064.
} 
tidak ada kegiatan aktivitas siswa dalam menemukan konsep dan dalam melakukan kegiatan pembelajaran, sehingga siswa kurang termotivasi apabila mengerjakan LKPD. Sedangkan dalam kurikulum 2013 siswa diharapkan LKPD yang ada dilengkapi dengan aktivitas-aktivitas agar siswa melakukan kegiatan pembelajaran sehingga siswa menjadi termotivasi. Diharapkan guru dapat menyusun dan membuat LKPD sendiri yang sederhana dan menarik, sehingga guru bisa menyesuaikan kemampuan peserta didik di kelas. Oleh karena itu haruslah sesuai dengan ketentuan yang sudah dibuat oleh pemerintah dan berkarakter, sehingga dapat memenuhi kebutuhan siswa ketika mempergunakannya. Melihat kondisi yang seperti inilah kemudian peneliti tertarik melakukan penelitian pengembangan yaitu perangkat Problem-Based Learning (PBL) Terintegrasi Keislaman terhadap SMP Muhammadiyah 2 Pekanbaru.

\section{Metode}

Penelitian ini di golongkan dalam penelitian pengembangan (Development Research) yaitu pengembangan untuk menghasilkan RPP dan LKPD dalam pembelajaran. Penelitian pengembangan memfokuskan kajian khususnya pada bidang desain atau rancangan dalam dunia pendidikan dan pembelajaran, apakah itu berupa model dan desain bahan ajar, produk misalnya media, dan juga proses ${ }^{8}$. Metode penelitian pengembangan (R\&D) merupakan metode penelitian yang menghasilkan produk tertentu yang digunakan untuk menguji keefektifan produk ${ }^{9}$. Penelitian dan pengembangan merupakan suatu proses pengembangan atau penyempurnaan suatu produk sebelumnya.

Penelitian ini dilakukan di SMP Muhammadiyah 2 Pekanbaru dengan waktu penelitian setelah perangkat pembelajaran dinyatakan valid oleh validator dan dapat digunakan pada mata pelajaran Matematika. Uji coba penelitian dilakukan di kelas VII SMP Muhammadiyah 2 Pekanbaru tahun ajaran 2018/1019 pada materi Himpunan. Waktu pelaksanaannya pada tanggal 7 September 2018 sampai 28 September 2018.

Teknik analisis data yang digunakan analisis deskriptif yang mendeskripsikan validitas perangkat yang di kembangkan dengan cara menghitung skor dari setiap indikator instrumen pengumpulan data yang di isi oleh validator.

\footnotetext{
8 Punaji Setyosari, Metode Penelitian Pendidikan \& Pengembangan (Jakarta: Fajar Interpratama Mandiri, 2013).

${ }^{9}$ Sugiyono, Metode Penelitian Kuantitaf Kualitatif Dan R\&D (Bandung: Alfabeta, 2012).
} 
Validasi instrumen penilaian ditentukan oleh rata-rata skor yang diberikan. Adapun kriteria dalam mengisi angket validasi seperti yang terlihat pada Tabel 1 berikut:

Tabel 1. Kategori Penilaian Lembar Validasi

\begin{tabular}{cc}
\hline Skor Penilaian & Kriteria \\
\hline 4 & Sangat Baik \\
\hline 3 & Baik \\
\hline 2 & Kurang Baik \\
\hline 1 & Tidak Baik \\
\hline \multicolumn{2}{l}{ Sumber: Modifikasi Mardapi (2008: 122) }
\end{tabular}

Rumus untuk analisis tingkat validitas secara deskriftif adalah sebagai berikut ${ }^{11}$ :

$$
V a_{1,2,3}=\frac{T S e}{T S h} \times 100 \%
$$

Untuk mengetahui hasil akhir dari validasi RPP dan LKPD dari para ahli maka rata-rata (mean). Adapun rumus validasi akhir adalah sebagai berikut:

$$
V=\frac{V a_{1}+V a_{2}+V a_{3}+\cdots+V a_{n}}{n}=\cdots \%
$$

Keterangan: $\mathrm{V}=$ Validitas gabungan

$\mathrm{n}=$ Banyak Validator

$\mathrm{Va}_{1}=$ Validitas dari ahli 1

$\mathrm{Va}_{2}=$ Validitas dari ahli 2

$\mathrm{Va}_{3}=$ Validitas dari ahli 3

$\mathrm{Va}_{\mathrm{n}}=$ Validitas dari ahli $\mathrm{n}$

$\mathrm{Va}=$ Validator ahli pada setiap RPP

$\mathrm{TSh}=$ Total skor maksimal yang diharapkan

$\mathrm{TSe}=$ Total skor empiris (hasil validasi dari validator)

Tingkat kriteria validitas disesuaikan berdasarkan Tabel 2 berikut:

Tabel 2.Kriteria Tingkat Validitas RPP dan LKPD

\begin{tabular}{ccl}
\hline No. & Kriteria Validitas & \multicolumn{1}{c}{ Tingkat validitas } \\
\hline 1. & $85,01 \%-100 \%$ & Sangat revisi. \\
\hline 2. & $70,01 \%-85 \%$ & Cukup revisi kecil. \\
\hline 3. & $50,01 \%-70 \%$ & Kurang besar. \\
\hline 4. & $01,00 \%-50 \%$ & Tidak dipergunakan. \\
\hline \multicolumn{2}{l}{ Sumber: Akbar $(2013: 158)^{12}$} &
\end{tabular}

${ }^{10}$ Djemari Mardapi, Teknik Penyususnan Instrumen Dan Notes (Bandung: PT. Remaja Rosdakarya, 2013).

${ }^{11}$ Sa'dun Akbar, Instrumen Perangkat Pembelajaran (Bandung: PT. Remaja Rosdakarya, 2013). 
Untuk mengetahui tingkat praktikalitas digunakan rumus sebagai berikut ${ }^{13}$ :

$$
P=\frac{\sum f}{N} \times 100 \%
$$

Keterangan:

$\mathrm{P} \quad=$ Persentase Praktikalitas

$f \quad=$ Perolehan skor

$N \quad=$ Total skor maksimal yang diharapkan

Kriteria tingkat praktikalitas mengikuti Tabel 3 sebagai berikut:

Tabel 3. Kriteria Tingkat Praktikalitas Perangkat Pembelajaran

\begin{tabular}{ccc}
\hline No & Nilai (\%) & Tingkat Praktikalitas \\
\hline 1 & $81-100$ & Sangat praktis \\
\hline 2 & $61-80$ & Praktis \\
\hline 3 & $41-60$ & Cukup Praktis \\
\hline 4 & $21-40$ & Kurang praktis \\
\hline 5 & $\mathrm{P}=20$ & Tidak praktis \\
\hline ber: Dimodifikasi dari Riduwan (dalam Hamdunah 2015: 38) &
\end{tabular}

\section{Validitas dan Praktikalitas Perangkat Pembelajaran}

Penelitian dilakukan di SMP pada hari Senin 13 Agustus 2018 sampai dengan Kamis 6 September 2018 merupakan penelitian pengembangan. 2 produk yang di uji cobakan yaitu RPP dan LKPD. Dalam hal ini peneliti mengembangkan produk RPP kurikulum 2013 dan LKPD dengan menggunakan terintegrasi keislaman. Dalam hal ini peneliti menggembangkan RPP sesuai dengan silabus kurikulum 2013. Langkahlangkah dalam Problem-Based Learning (PBL) ini adalah : 1. Masalah, 2. Menanya, memunculkan permasalahan, 3. Menalar, mengumpulkan data, 4. Mengasosiasi, merumuskan jawaban, 5. Mengomunikasikan.

Peneliti melakukan validasi terhadap perangkat yang dibuat oleh peneliti. Peneliti melakukan validasi pada produk kepada 3 orang validator. Dari hasil analisis RPP dan LKPD maka diperoleh hasil seperti yang terlihat pada Tabel 4 berikut:

\footnotetext{
${ }^{12}$ Akbar.

13 Hamdunah, "Praktikalitas Pengembangan Modul Kontruktivisme Dan Website Pada Materi Lingkaran Dan Bola," Lemma: Research of Mathematic Education 2, no. 1 (2015), https://doi.org/10.22202/j1.2015.v2i1.524.

${ }^{14}$ Hamdunah.
} 
Tabel 4.Hasil perhitungan Validasi RPP

\begin{tabular}{|c|c|c|c|c|c|}
\hline \multirow{2}{*}{ RPP } & \multicolumn{3}{|c|}{ Persentase Validitas (\%) } & \multirow{2}{*}{$\begin{array}{l}\text { Rata-rata } \\
\text { (\%) }\end{array}$} & \multirow{2}{*}{$\begin{array}{l}\text { Tingkat } \\
\text { Validitas }\end{array}$} \\
\hline & V1 & V2 & V3 & & \\
\hline RPP-1 & $81,25 \%$ & $76,56 \%$ & $82,81 \%$ & $80,20 \%$ & Cukup Valid \\
\hline RPP-2 & $82,81 \%$ & $79,68 \%$ & $84,73 \%$ & $82,41 \%$ & Cukup Valid \\
\hline RPP-3 & $81,82 \%$ & $75 \%$ & $82,82 \%$ & $79,88 \%$ & Cukup Valid \\
\hline RPP-4 & $81,82 \%$ & $75 \%$ & $81,82 \%$ & $79,55 \%$ & Cukup Valid \\
\hline RPP-5 & $78,12 \%$ & $76,56 \%$ & $85,93 \%$ & $80,20 \%$ & Cukup Valid \\
\hline RPP-6 & $79,68 \%$ & $73,44 \%$ & $87,5 \%$ & $80,21 \%$ & Cukup Valid \\
\hline \multicolumn{4}{|c|}{ Rata-rata Total } & $80,40 \%$ & Cukup Valid \\
\hline
\end{tabular}

Berdasarkan hasil penilaian dari tiga orang validator pada Tabel 4 maka untuk pertemuan pertama sampai dengan pertemuan keenanm memiliki tingkat validitas cukup valid dan telah melalui dua kali proses validasi uji coba sesuai dengan revisi kecil.

Tabel 5. Hasil Perhitungan Validasi LKPD

\begin{tabular}{|c|c|c|c|c|c|}
\hline \multirow{2}{*}{ LKPD } & \multicolumn{3}{|c|}{ Persentase Validitas (\%) } & \multirow{2}{*}{$\begin{array}{c}\text { Rata-rata } \\
\text { (\%) }\end{array}$} & \multirow{2}{*}{$\begin{array}{c}\text { Tingkat } \\
\text { Validitas }\end{array}$} \\
\hline & V1 & V2 & V3 & & \\
\hline LKPD-1 & $77,38 \%$ & $75 \%$ & $75 \%$ & $75,79 \%$ & Cukup Valid \\
\hline LKPD-2 & $78,57 \%$ & $75 \%$ & $83,33 \%$ & $78,96 \%$ & Cukup Valid \\
\hline LKPD-3 & $72,62 \%$ & $75 \%$ & $78,57 \%$ & $75,39 \%$ & Cukup Valid \\
\hline LKPD-4 & $77,38 \%$ & $73,81 \%$ & $83,33 \%$ & $78,17 \%$ & Cukup Valid \\
\hline LKPD-5 & $77,38 \%$ & $72,62 \%$ & $82,14 \%$ & $77,38 \%$ & Cukup Valid \\
\hline LKPD-6 & $76,19 \%$ & $70,24 \%$ & $84,52 \%$ & $76,98 \%$ & Cukup Valid \\
\hline \multicolumn{4}{|c|}{ Rata-rata Total } & $77,11 \%$ & Cukup Valid \\
\hline
\end{tabular}

Berdasarkan hasil penilaian dari tiga orang validator pada Tabel 5 maka untuk pertemuan pertama sampai dengan pertemuan keenanm memiliki tingkat validitas cukup valid dengan revisi kecil.

Tabel 6. Tingkat Praktikalitas Perangkat Pembelajaran

\begin{tabular}{cccc}
\hline $\begin{array}{c}\text { Persentase Lembar } \\
\text { Respon Guru (\%) }\end{array}$ & $\begin{array}{c}\text { Persentase Lembar } \\
\text { Respon Siswa (\%) }\end{array}$ & $\begin{array}{c}\text { Rata- } \\
\text { Rata }\end{array}$ & $\begin{array}{c}\text { Tingkat } \\
\text { Praktikalitas }\end{array}$ \\
\hline $83,82 \%$ & $86,23 \%$ & $85,03 \%$ & Sangat Praktis \\
\hline $\begin{array}{c}\text { Rata-rata Praktikalitas Perangkat } \\
\text { Pembelajaran (\%) }\end{array}$ & $85,03 \%$ & Sangat Praktis \\
\hline
\end{tabular}

Berdasarkan Tabel 6 diatas tersebut diperoleh rata-rata praktikalitas perangkat pembelajaran sebesar $85,03 \%$ praktis.

\section{Penutup}

Simpulan 
Telah dihasilkan perangkat pembelajaran matematika berupa RPP dan LKPD dengan Terintegrasi Keislaman pada materi Himpunan kelas VII SMP yang teruji kevalidan dan kepraktisannya

Saran

Berdasarkan pada kesimpulan dan pembahasan hasil penelitian yang telah dikemukakan, peneliti memberikan saran bahwa pembelajaran terintegrasi keislaman bisa meningkatkan motivasi belajar tentang nilai keislaman salah satunya pelajaran matematika, dan tidak menuntut kemungkinan pelajaran lain juga dapat menintegrasikan nilai islam juga diharapkan dapat diterapkan di semua jenjang pendidikan sampai jenjang perkuliahan.

\section{Daftar Pustaka}

Akbar, Sa'dun. Instrumen Perangkat Pembelajaran. Bandung: PT. Remaja Rosdakarya, 2013.

Amri, Sofan. Pengembangan Dan Model Pembelajaran Dalam Kurikulum 2013. Jakarta: Prestasi Pustaka, 2013.

Fitriah, Nani, Arif Muchyidin, and Jamali Sahrodi. "Implementasi Model Pembelajaran Matematika Berintegrasi Keislaman Dalam Meningkatkan Karakter Demokrasi Siswa." Eduma: Mathematics Education Learning and Teaching 4, no. 2 (June 4, 2015). https://doi.org/10.24235/eduma.v4i2.34.

Hamdunah. "Praktikalitas Pengembangan Modul Kontruktivisme Dan Website Pada Materi Lingkaran Dan Bola." Lemma: Research of $\begin{array}{lllll}\text { Mathematic Education } & \text { 2, no. } & 1 & \text { (2015). }\end{array}$ https://doi.org/10.22202/jl.2015.v2i1.524.

Kosasih, E. Strategi Belajar Dan Pembelajaran Implementasi Kurikulum 2013. Bandung: Yrama Widya, 2014.

Kunandar. Penilaian Autentik (Penilaian Hasil Belajar Peserta Didik Berdasarkan Kurikulum 2013). Jakarta: PT. Rajagrafindo Persada, 2014.

Mardapi, Djemari. Teknik Penyususnan Instrumen Dan Notes. Bandung: PT. Remaja Rosdakarya, 2013.

Nihayati, Nihayati. "Integrasi Nilai-Nilai Islam Dengan Materi Himpunan (Kajian Terhadap Ayat-Ayat Al-Qur'an)." Jurnal E-DuMath 3, no. 1 (January 30, 2017). https://doi.org/10.26638/je.285.2064.

Setyosari, Punaji. Metode Penelitian Pendidikan \& Pengembangan. Jakarta: Fajar Interpratama Mandiri, 2013.

Sugiyono. Metode Penelitian Kuantitaf Kualitatif Dan R\&D. Bandung: Alfabeta, 2012.

Trianto. Model Pembelajaran Terpadu Dalam Teori Dan Praktek. Jakarta: Prestasi Pustaka, 2007. 